\title{
THE PROPRIETIES OF STIGMA AND THE SITUATION OF HUMAN LIFE IN DANGER OF STIGMA
}

\author{
MAGDALENA ŚWIGOST
}

\begin{abstract}
It is stated that the properties of stigma have the key role in perceiving social relations and own life situation by the person who is in danger of the process of social stigma (Davidio, Major and Crocer, 2008, p. 27-28). It is cognitively interesting how agreeing to the process of social stigma is shown in terms of difficulty that is being activated by specific feature, pressing, in exceptional sense, on seeing and controling the stigma.

This article contains the theoretical analysis of the process of social stigma in relation to its chosen features. There has been done an attempt to present mutual assorted interaction with the influence of blocking predicators or those restoring the process of social self-indicating and indicating.
\end{abstract}

Keywords: stigma, assorted interaction, properties of stigma, self-indication, indicating.

\section{INTRODUCTION}

In situations in which people meet a panger, information that shows us what kind of person we deal with, how he or she looks like, what believes and social group represents - those features are useful only when we are able to draw conclusions relating to benefits or losses that may come along with it [2, p. 114]. The key information in this field is that they are straightforwardly connected to the features of the perceived stigma in the sense of theinterpersonal relation. This is also why there will be presented the moment of meeting between the person of sigma with the stigma itself, bearing in mind the aspect of the characteristics of stigma. There was also undertaken an attempt to demonstrate the influence of visibility of the stigma as well as its controllability in the sense of perceiving the person who experiences the results of having a feature of being able to deal with troublesome situations that were created in the assorted relations [1, p. 27-28].

As it was already mentioned, the significant feature in the process of the encounter between the person that experiences the results of stigma with the perceiver, is the visibility of having the stigma. Relaying on the given criteria, E. Goffman [11, p. 34; 3, p. 1103] distinguished two descriptive categories. A person may have two features:

1) Discreditation (visible) - in situations where the features known as "worse" are visible right away or an individual presumes that the environment knows about its existence (i.e. visible obesity or disability). 
2) Discreditation (invisible) - the stigma is invisible in situations of regular interpersonal relations. An individual presumes that the environment does not know about its (i.e. homosexualism, analphabesism).

\section{ANALYSIS AND Discussion}

The visibility and the ability to hide the stigma has an essential influence on the formation of the assorted relations because there exist diverse issues that relate to mutual encounter. There also are various pategies of dealing with the fact of being different. Each of the given situation distinguishes between the specificity of issues that inevitably happen to every person on daily basis.

In the case of visibility of the stigma there appear issues of auto presentation, adequate interpretation of reactions and requirements of the society as well as adapting to the social audience of own behavior. There also appears a boundless influence discrediting on the picture of oneself and the person's interpersonal relations [4, p. 57]. Accordingly to the ecological theory of social perception, people are sensitive when it comes to their appearance. The information that is provided by their visible features, usually becomes general $[5$, p. 23], i.e.: slim figure and neat look may mean the ability to self-control, however, obesity may be the feature of the sigma [6, p. 35]. The society expectations towards a person with a visible stigma noticeably limits a dialog or social interactions. Relations become superficial and their participants want to end them as soon as possible [4, p. 57].

Scientific research confirms that the first impressions are relevant as well. One of the psychological experiments was undertaken by S. Asch [7, p. 63]. He read to the participants a profile of a person that consisted of a short list of adjectives and asked them to share with their impressions of this person. One of the groups got the description of the positive features first, and then the negative and the other group firstly heard about bad things and then about the nice ones. The results showed that each group made their first impression of a person by the first part of the text. What comes with this, despite both of the texts being the same, the first words shaped the minds of the participants. The next research only confirmed the thesis.

The variable that is usually mentioned as playing the key role is the perceived level of resemblance between the person who evaluates and the evaluated. People usually are attracted to those who represent the same or similar values in life to their own [7, p. 63-64]. The mechanism is especially important to those with the visible stigma. In the situation where the feature of stigma is im possible, either visible or invisible, there appears a disrupted self-consciousness. The subject of perceivance encounters numerous issues in the interaction because, although the socialization, he acquired an ability to enter into relationships with other person, however, when there occurs a disturbance in the relation, he does not know how to deal with the situation. Variability of interactions usually causes embarrassment or shyness. The additional issue is the selection of adequate description of categories towards the person with the stigma [8, p. 197].

Moreover, the participants of the assorted interaction confront with the causes and results of the stigma. In the giver situation, a person with a stigma may experience: uncertainty to the way of how he or she is going to be perceived or judged, that he or she is not going to be taken seriously as a regular human being in everyday life. As for example: such person is conscious that even small achievements can be perceived as some kind of extraordinary abilities; the feeling of presence among people who judge one another gives an impression of violating own privacy (i.e. when children stare at a "different" peer); there comes to mind of the judged person an urge to run away and avoid such situations. What is more, usually there occurs a pong defensive position in social interactions $[11$, p. $45-50]$.

It is said that one of the main possibility of the person who burdens the stigma is a hard work to intentionally behave "like the normal people" among others and to act as if being different is something irrelevant and unnoticeable [11, p. 77]. Considering this issue, it is worth to look closely into the social situation that is caused by disability. There was also pointed that there is no such other group like this one with disabilities that would be equally open to participate in the main social movement to which 
taking part in a public life was a relevant component of effective rehabilitation (Riessman i Carroll). However, when in an encounter with a person that the appearance differs from the wide understanding of "regular", meets with a wide range of emotions. Such thing directs us somehow to the specific way of perceiving such people and the inevitable excitement that accompanies the situation causes a ping impulse to take actions. For example: something that evokes fear, provokes to its avoidance or an escape [9, p. 247]. What comes with this, in such inconvenient situations that are triggered by disabilities, there are evident contrasting verbal and nonverbal behaviors of those without disabilities. It is commonly known that people should be kind, show empathy and compassion to those with disabilities [10, p. 391]. As it follows, the verbal interactions are usually very positive, however, it can be noticed that in the non-verbal behavior there appear avoiding and stiffness of movements, more distance during interactions as well as less spontaneity [11, p. 185]. People usually try to show the semblance of authenticity (as it is required by the social context), however, situations in which we do not know what to do, we can still be full of fear and awkwardness [12, p. 265]. The overt manner and posture is undisputedly connected with previous thinking about behavior, however the hidden spontaneousness and uncontrolled reaction to a specific situation still occurs [11, p. 185]. What is more, when facing the divergence, we usually meet with more attitude of resignation and subjection than with any interference because such requires specific knowledge on the topic of the given situation as well as ability to predict consequences [13, p. 197].

In such situations there is only possibility of attempt to make the circumstances as socially normal as we can. F. Davis [13] distinguishes three stages on the path of the attempt. The first one is the fictional acceptation where we can observe the situations that are resulting of kindness, good behavior and some kind of courtesy. Then, in the faze known as the transition, the observer starts to see the other person in different way noticing his or her advantages that are usually noticed only by their "codisabled". The next phase is the normalized interaction of institutionalization where being different is perceived as a part of human personality that exists but does not interfere with regular interaction. The process is identified by the people who are experienced of the stigma. Such people claim that they can easily recognize the types of behavior presented above. One of the examples is the behavior of people who talk with the blind - they try to speak slow and clear [8, p. 114].

It is said that because of the numerous benefits of being considered as a "normal" person, almost everyone who has the ability to skip their stigma, to will to this on some occasion [14, p. 113]. Such situation may happen when we meet in the case of a hidden stigma. Then, when talking about interpersonal relationships, it is more about the efficient management of awkward information. Along with the need to conceal the stigma, it is necessary to anticipate possible relations from the environment. The analysis of the situation that potentially threaten to expose it and also an attem pt to avoid them as well as create and develop masking situation [3, p. 1103]. Secrecy is becoming more absorbing and the attempts to maintain the mystery activate a set of cognitive process that in turn can lead to obsessive thinking about the stigma. When a man with a hidden stigma is actively trying to conceal it, then the secret may be more accessible only when there would be undertaken more effort to not to think about it. The process is so painful, that perhaps the greater desire that a person with hidden stigma could be, not even a lack of it but also a disappearance of its thoughts [15, p. 208]. The divergence is thus a kind of helplessness and configuration of fear [13, p. 197].

The situation of keeping secrets makes the person not only juggle with the fact that he possesses a quality that is not acceptable in the world but is also controversial with his own obsessive preoccupation of the stigma. This absorption usually influences the overall way in which it functions. Moreover, psychological research shows that even when such people consider trying to suppress their thoughts about their stigma, they still affect on their behavior and judgement [15, p. 208]. These efforts, however, are often undertaken because keeping own discrediting feature as a secret, often makes it possible to integrate into the mainstream of social life. It is needed to notice that the stigma affects longterm relationships stronger than the short-term interactions with the environment. This is explained by the fact that it is harder to keep a secret in deeper relationships, so such people may choose superficial contacts in which the stigma is relatively easy to hide [15, p. 209]. 
There remains a question whether to deal with everyday situations with the effects of stigma. Literature indicates numerous cases - useful depending on the character of the stigma and a context which are observed in behavior of stigmatized people. It is worth to enumerate some of the basic ones [11, p. $40-41 ; 16$, p. 31-32; 15 , p. 217-218].

1. Undertake a direct correction of what is seen as an objective basis for its handicap - for exam ple, plastic surgery. Unfortunately, it is often a result of a change of identity from someone who has a certain visible characteristic into someone who has only his or her corrections.

2. Make an effort to master those areas of activity that are unreachable to someone with a specific stigma (for example, mountain climbing undertaken by people with mobility disabilities).

3. Break with the so-called reality and insist on own interpretation of own social identity.

4. Draw from the profit of stigma justifying any failure in other areas of own life.

5. Reflect the stigma into something else (i.e. drug addicts sting in less visible places that veins on their hands).

6. Divide the world into two parts - we can differentiate the big group that does not know anything about the stigma and a little one that knows about the stigma everything.

7. Tell everyone about the stigma - the discredit stigma changes into the stigma with discredited properties. It does not have to manage the embarrassing information but it should deal with uncertain social situation.

8. In the case of an invisible stigma, there can be developed a mechanism that would automatize the damping. Over time, hiding the secret is more effective. For example, an entity with a criminal background, after many years of keeping it secret may state that it is easier to hide.

9. Directing the situation in such way as to protect oneself from keeping the secret and using the attenuation by avoiding the circumstances in which it is necessary to hid to stigma.

10. Re-define a stigma, meaning, interpret it in such a way that it is no longer stigmatized or at least no longer relevant to matters relating to the identity of the person concerned. Then a person can forget about it because active .keeping a secret stops being needed.

11. A person that experiences own stigma may project this difference to the person in his or her surrounding, stating that they are physically or morally different. This way of looking at the world may be one of the unconscious by-products of concealing the stigma. It is also possible to conduct a world in which their stigma is perceived as more widespread than it is in reality. This way of thinking can temporarily relieve stress.

It is worth to mention that people with a visible stigma usually focus more on the environment and on the physical characteristics of the people interactions than on the content of their conversations. Those with the hidden stigma, on the other hand, usually focus their attention on the content of the conversation - which is important - often taking the view of their partners. This subtle difference reflects perceptual changes, depending on the visibility of the main determents of stigma. In general, the first group should focus on already "broken interaction" and remain alert to the signs of the person's true attitudes and feelings. People with the invisible stigma should focus more on controlling the conversation and pay attention to what is being said. They should also try to read thought of their partner in a way as to allow further concealment of the stigma [15, p. 212].

The immense influence on the process of stigmatization means its controllability and lack of control over its. In cases in which there occurs a violation of the rules of social coexistence, social response may be classified as well as a punitive criticism that is motivated by the need to punish a the person for what she or he did [17, p. 302]. As for an example: the public opinion about the blind is different about a person who leaves the penal institution (in both cases the stigma is very severe but differently judged). The reluctance of the surroundings or the rejection of the person is caused by fear, the feeling that the source of the stigma is the person itself $[18, \mathrm{p}$. 87]. The process of stigma begins at the time of the investigation and arrest when it is being told to the suspect belongs (or may be) to a criminal social minority. Proceeding of the judicial authorities culmination with a conviction means the first stage of institutionalization the loss of freedom is for many people a proof that they have been rejected by the free society. The next stage of stigma is already taking place in a closed institution which has the right 
and means for further labeling those who are within it. Throughout the period of imprisonment and after being released into the wilderness, it is recalled to a man that he has lost the status of a normal citizen and was classified as a criminal [19, p. 216].

This situation is extremely difficult to get rid of stigma. The ancient Greeks were marking their slaves with a sign so that they would not be able to hide their identity. Today, people can find similar practice in the prison subcultures. The prisoners tattoo the symbols willingly or are forced to do so by their fellow prisoners - but not a symbol of the tattoo on the body but a symbol on the people's identity is the problem in the world. The prison tattoo can be removed and many people do not know its meaning. Nowadays, it has a completely different meaning than in the Ancient Greece. The image of the "embedded" still remains inside a human mind. Many scientists claims that it is not possible to reintegrate former prisoners because they were not well integrated with the society. Therefore, the idea of the integration is an illusion. If in such social thinking prevails consciousness, people with such stigma will never be fully in the mainstream of the society [20]. Moreover, people who have left the prison often have issues in finding a job. At the point when the employer finds out about a previous punishment, the problem of possible em ployment becomes more problematic. In addition, the closest local community treats this person as marked by many negative features. The feeling of being "worse" and the lack of chances for better, normal life causes a return to the deviant fulfilling of the roles in society $[21 ; 8$, p. 110]. It can be said that social expectation for the people with a stigma is often irrelevant and have a negative coloration. The inability of perceptions rooted in stereotypes, lack of knowledge and results from negative comparisons with other. Such occurrence may lead to the conclusion that the different: person is misunderstood and perceived as an alien in the society.

The situation of people with disabilities who can not to be blamed for their social handicaps, positively affects the attitudes. Nevertheless, it is stated that "disability is traditionally referred to apart from crime, economic or cultural degradation - are the most common cause of social exclusion" [22, p. 116]. It is mainly connected to the fact that the evident differences as well as organic hindrances which compromise the balance between what a person lives for, wants and needs, and the ability to achieve own goals.

Addressing the issue of control and visibility of the stigma, it seems necessary to clarify the question of "self-fulfilling prophecy". As for example: the belief that people with a disability are dependent may cause us to behave in a particular way, and, paradoxically, they cause dependent behavior. The greater there is a certainty to occur of specific behaviors (own's or the other's), the greater is the probability of the occurrence of the self-fulfilling prophecy [21, p. 111]. Similarly, the return of people previously imprisoned and deprived of liberty for criminal activity confirms the social classification in terms of anger and the need for them to take further severe penalties [21]. The presented phenomenon can also be explained by the theory of self-affirmation, where it is assumed that people have the need to confirm their notion, whether it is positive or negative, which in certain situations may be in conflict with the need to maintain good self-image [23, p. 454].

The story of a person with stigma is always a dram a that unfolds in time. In situations where occurs a gradual, progressive change process, for example, people who have just gone out of an addiction must be prepared for the stigma to be a burden long after leaving the therapeutic facility - maybe even for the rest of their lives [8, p. 112]. Certain characteristics corresponding to the stereotype of a "drug addict" will be attributed to him or her despite dealing with the problem. Such thing happen because the addict is treated as unworthy of rust, with weak will and as somebody dangerous. The person is generally blamed for his or her current social status as well. There is a belief that a person may be saved before being addicted by for example not entering on the path where there are many dangerous people that are dealers. Nevertheless, the fact of taking a treatment can be perceived as a form of compensation. Furthermore, if we present an addicted person as being addicted because of previous treatment, the society is more likely to understand and be show less anger [24, p. 85-86; 25, p. 184].

The issue of attributing a blame for current social status is a key role to the social perception of a particular identity. Moreover, experiencing guilt is in some situations almost required from the point of view of social expectations. This particular situation concerns especially those who have committed 
crimes, thereby violating the principle of reciprocity. Under such circumstances, it is required from a person to show a feeling of guilt. Then, there appears the possibility of causing a feeling of compassion, sympathy as well as reducing the severity of a punishment from a judge and people involved in the case. Those who observe the signs of experiencing those kind of emotions are the proof that the convicted is not "totally bad" and there appears a hope for this person's recovery as well as re-inclusion to the community [26, p. 118]. The research of J. Bielecka-Prus confirms that a presentation (often fake) of guilt during court proceedings appears very often. Such treatments confirm the statements of the respondents gathered by the author of these studies, who described the situation at the court hearing: "I pretended not to be worse but I did not feel guilty"; "I show the regret, I make sad expression, I apologize and I say it will not happen again"; "I try to cry but I cannot. I dropped my eyes and said nothing"; "In court you always have to show the regret so that the court knows that I really regret. What for? To have a smaller sentence" [25, p. 104-123].

All these treatments are used to maintain a positive self image and reduce the social distance that is created in mixed relationships. There are several hypothesis confirmed by scientific studies that, in some extent, explain the predicators of the increase or decrease. It was considered mainly by economic, social and cultural factors [27, p. 194]. Additionally, it is noted that, generally, the older people are exposed to certain (labeled) social class. Gender is not a differentiator any more. The high degree of the distance is poorly linked to low education as well, while the cultural differences significantly affect its intensity [25, p. 184]. Numerous studies confirm that the contact (personal experience of a relationship with a person with potential stigma) significantly reduces the degree of social distance, while other research is not clear of the impact of knowledge on specific groups on the given displayed distance. It is also worth to pay attention to the context of the discussed here dependency between the fact that if the stigma is connected to the weakness of character (and so in the common thought with the possibility of attributing the fault to the experienced difficulties), the distance is generally higher.

The research on the level of social distance also confirms that if some groups are perceived in terms of risk, the factor significantly increases its intensity. Factors that can help to decrease the distance are to optimize the balance between members of unequal status groups and strengthen their cooperation for close relationships between group members. It is believed that these basic factors may reduce embarrassment in relationships, anxiety and uncertainty [28, p. 452].

\section{CONCLUSIONS}

The special attention in social psychology is centered around the "contact hypothesis" which states that contact between members of the group leads to reduction in the level of mutual prejudice and to improvement of overall intergroup relations. This is one if the oldest concepts of psychology, but nevertheless it still arouses a lot of interest [29, p. 63]. It was agreed, however, that contact between groups leads to prejudice only when there are fulfilled the requirements of the relationship between small groups. As for an example: M. Sherif has emphasized the role of the collaboration between groups and interdependencies, G. Allport listed 4 situational requirements for effective contact: equal status of groups; daily co-operation; common goals; supporting the authorities and laws [29, p. 63]. Nowadays, people talk of the need for personalized contact that would serve to reduce the social distance between the "own" group and the "other" group. The "foreign" one is seen as relatively inferior, denser and distinct in contrast to the "self" group. On theother hand, if there are differences in the category of self and foreign groups, some members of the both groups would be perceived as unusual. With the increase of the perceived diversity the boundaries of groups appear to be more and more unstable and permeable. Eventually, the group membership becomes completely irrelevant. It is believed that only personalized interaction, which implies the perception of oneself in terms of personal attributes and not belonging to a particular social category, effectively suppresses the social distance $[29$, p. 66].

It is all about the overcoming of categorization, which is the basis for starting the process of stereotyping. The perception of the individual who, by the virtue of his or her character, falls within 
one category of the social group commonly regarded pejoratively, will cause us to assign it all the features of that category regardless of its reals properties. The image of the individual world is constantly reinterpreted and is made in the process of interaction between an individual and the social, cultural and material environment - and this is in that individual that verifies the reality of the categorical views available and gains some kind of independence in that relation [30, p. 79]. Observing the differences between members of strangers and, above all, recognizing their capital, have a pong factor in weakening the process of stigma. The process of establishing the meaning in the social context is crucial to the daily living situation of a person who is at risk of the result.

Artykuł stanowi skrócona wersję tekstu złożonego do druku w czasopiśmie Zeszyty Pracy Socjalnej wydawanym przez Wydawnictwo Uniwersytetu Jagiellońskiego.

\section{REFERENCES}

[1] Davidio J.F, Major B., Crocer J. Piętno: wprowadzenie i zarys ogólny. In: Heatherton T.F. (Eds.) Społeczna psychologia piętna. PWN, Warszawa, 2008. (in Polish)

[2] Czapiński J. Przesłanki ustosunkowań wobec innych ludzi. In: Lewicka M. (Eds.) Psychologia spopzegania społecznego. Książka i Wiedza, Warszawa, 1985. (in Polish)

[3] Błeszyńska K.M. Stygmatyzacja. In: Pilch T. Encyklopedia pedagogiczna XXI wieku. Żak, Warszawa, 2006. (in Polish)

[4] Szewetowska K. Stygmatyzacja społeczna. Edukacja i Dialog, 4 (2009), 56-60. (in Polish)

[5] Wojciechowski F. Niepetnosprawność, rodzina, dorastanie. Żak, Warszawa, 2007. (in Polish)

[6] Green G. The end of stigma? Changes in the social experience of long-term illness. Routladge, New York, 2009.

[7] Sutton C. Psychologia dla pracowników socjalnych. GWP, Gdańsk, 2004. (in Polish)

[8] Czykwin E. Stygmat spoteczny. PWN, Warszawa, 2008. (in Polish)

[9] Lachowicz-Tabaczek M. Emocje umystu: rola potocznych koncepcji świata i natury ludzkiej w regulacji percepcji zachowań. In: Kossowska M., Kofta M. (Eds.) Psychologia poznania społecznego. PWN, Warszawa, 2008. (in Polish)

[10] Hebl J.G., Kleck R.E. Społeczne konsekwencje niepetnosprawności fizycznej. In: Heatherton T.F. (Eds.) Społeczna psychologia piętna. PWN, Warszawa, 2008. (in Polish)

[11] Maliszewski N., Czyżewska M., Krejtz I. Postawy jawne a postawy ukryte jako wyznaczniki poznania $i$ zachowania społecznego. In: Kossowska M., Kofta M. (Eds.) Psychologia poznania społecznego. PWN, Warszawa, 2009. (in Polish)

[12] Hebl M., Tickle J., Heatherton T. Kłopotliwe momenty w interakcjach między jednostkami niestygmatyzowanymi a stygmatyzowanymi. In: Heatherton T.F. (Eds.) Społeczna psychologia piętna. PWN, Warszawa, 2008. (in Polish)

[13] Perzanowski A. Odmieńcy. Antropologiczne studium dewiacji. DiG, Warszawa, 2009. (in Polish)

[14] Goffman E. Piętno. Rozważania o zranionej tożsamości. GWP, Gdańsk, 2007. (in Polish)

[15] Smart L., Wagner D.M. Ukryte koszty ukrytego piętna. In: Heatherton T.F. (Eds.) Społeczna psychologia piętna. PWN, Warszawa, 2008. (in Polish)

[16] Świątkiewicz-Mośny M. Tożsamość napiętnowana. Socjologiczne studium stygmatyzacji i autostygmatyzacji na przykładzie kobiet z zespołem Turnera. NOMOS, Kraków, 2010. (in Polish)

[17] Williams K.D., Wheeler L., Harvey J.A. Podróż w głab umystu społecznego osoby stosujacej opacyzm. In: Forgas J.P., Williams K.D., Wheeler L. (Eds.) Umysł społeczny. Poznawcze i motywacyjne aspekty zachowań interpersonalnych. GWP, Gdańsk, 2005. (in Polish)

[18] Stangor Ch., Crandall Ch.S. Zagrożenie i społeczna konpukcja piętna. In: Heatherton T.F. (Eds.) Społeczna psychologia piętna. PWN, Warszawa, 2008. (in Polish)

[19] Ciosek M. Psychologia sadowa i penitencjarna. Stella Marius, Warszawa, 2001. (in Polish) 
[20] Brzezińska A. Struktura obrazu własnej osoby i jego wpływ na zachowanie. Kwartalnik Pedagogiczny, 3 (1973), 87-97. (in Polish)

[21] Pikor B., Antończak S. Piętno pobytu w zakładzie karnym. listopad 20, 2014. Available at: http://www.wszia.edu.pl/images/old/prace_kol_zeszyt4/17.pdf. (in Polish)

[22] Kosek-Nita B., Raś D. Kontakty z ludźmi "innymi" jako problem wychowania, opieki i resocjalizacji. UŚ, Katowice, 2007. (in Polish)

[23] Aronson E., Wilson T., Akert R. Psychologia spoteczna. Zysk i S-ka, Poznań, 2006. (in Polish)

[24] Dijker A.J.M., Koomen W. Stygmatyzacja, tolerancja i naprawa. Integracyjna analiza psychologiczna reakcji na dewiację. Fundacja "Tolerancja”, Białystok, 2009. (in Polish)

[25] Jorm A., Oh. E. Desire for social distance from people with mental disorders. Australian and New Zealand Journal of Psychiatry, 43 (2009), 183-200. doi: 10.1080/00048670802653349

[26] Bielecka-Prus J. Poczucie winy jako emocja społeczna. Analiza wybranych nurtów badawczych. Przegląd Socjologii Jakościowej, 9 (2) (2013), 104-127. (in Polish)

[27] Bottero W., Prandy K. Social interaction distance and stratification. British Journal of Sociology, 54 (2) (2003), 177-197.

[28] Anagnostopoulos F., Hantzi A. Familiarity with and social distance from people with mental illness: Testing the mediating effects of prejudiced attitudes. Journal of Community and Applied Social Psychology, 21 (2011), 451-460.

[29] Bilewicz M. Kiedy kontakt osłabia uprzedzenia? Kategoryzacje społeczne i temporalne jako warunki skutecznego kontaktu międzygrupowego. Psychologia Społeczna, 2 (2006), 63-74. (in Polish)

[30] Ostafińska-Molik B. Postrzeganie siebie i własnego zachowania w kontekśsie zaburzeń adaptacyjnych młodzieży. WUJ, Kraków, 2014. (in Polish)

Address: Magdalena Świgost, Institute of Pedagogy of the Jagiellonian University, 12, Batorego Str., Kraków, 31-135, Poland.

E-mail: magdalena.swigost@uj.edu.pl.

Received: 02.11.2017; revised: 30.03.2018.

Свігост Магдалена. Властивості стигми та ситуації людського життя. Журнал Прикарпатського університету імені Василя Стефаника, 5 (1) (2018), 47-54.

У статті встановдено, що властивості стигми відіграють ключове значення у сприйнятті суспільних відносин та власної життевої ситуації особою, яка перебуває під загрозою соціальної стигматизації [1, p. 27-28]. Це є надзвичайно цікава проблема для дослідження, оскільки вона узгоджується з процесом соціальної стигматизації, виявляється у низці труднощів, які активуються за певними ознаками.

Ця стаття містить теоретичний аналіз процесу соціальної стигми на основі обраних ознак. Автором здійснено спробу представити взаємозв'язану різноманітну взаємодію 3 впливом блокувальних предикаторів або тих, що відновдюють процес соціальної самоіндикації та індикації.

Ключові слова: стигма, взаємодія, властивості стигми, самоіндикація, показання. 